\title{
Knowledge, Acceptance and Application of Islamic Financial Management among Small and Medium Enterprises (SMEs) Halal Entrepreneurs in Peninsular of Malaysia
}

Mohd Daud Awang, Junaina Muhammad, Muhamad Nur Aiman Mohd Noor, Amalina Abdullah, Amini Amir Abdullah, Norsazali Abdullah, and Dayang Shobihah Abang Abai

Corresponding Author: Mohd Daud Awang amdaud@upm.edu.my

Received: 2 May 2020 Accepted: 4 July 2020 Published: 14 July 2020

Publishing services provided by Knowledge E

(c) Mohd Daud Awang et al. This article is distributed under the terms of the Creative Commons Attribution License, which permits unrestricted use and redistribution provided that the original author and source are credited.

Selection and Peer-review under the responsibility of the ICIEHI Conference Committee.

\section{Abstract}

The Halal industry in Malaysia has created employment opportunities especially among Small and Medium Enterprises (SMEs). High demand for Halal products especially from Islamic countries has transformed the development of this sector into a national priority. In the Eleventh Malaysia Plan (11MP), the competitiveness of the Halal industry was given special emphasis by the Prime Minister. In Asia, Malaysia has long been considered as a leader in the development of the Halal sector. However, the Halal industry is not only about Halal food production, but also covers Islamic finance services which prohibit interest (riba), uncertainties (gharar) and gambling (maysir). Islamic financial management is one of the important parts of Islamic finance because it plays a big role in providing Shariah-compliant funds and investment opportunities especially for the SME Halal entrepreneur. The holistic approach to the Halal industry should also cover not only food production but also Islamic financial management which includes activities such as how to create, increase, purify and to protect wealth from an Islamic perspective. Therefore, this study examines the relationship between the knowledge and acceptance of Islamic finance, and the application of Islamic financial management among halal entrepreneurs in Peninsular Malaysia. The findings of this study reveal that the knowledge and acceptance of Islamic finance is significantly correlated with the application of Islamic financial management among halal operators of SMEs. This indicates that to integrate the Halal industry with Islamic financial management activities, Halal entrepreneurs should be able to know and accept the Islamic finance principles. This will, in turn, facilitate the promotion of Malaysia's Halal industries on the global stage.

Keywords: Halal Industry, SMEs Halal entrepreneur, Islamic Financial Management

\section{Introduction}

\section{G OPEN ACCESS}

The global halal market size is expected to reach USD9.71 trillion by 2025 . Economic development of leading Islamic countries such as Indonesia, Malaysia, India, Pakistan, 
Nigeria, and Iran is expected to boost the global halal products market the coming years (Reuter, Jan 10, 2019). In Malaysia halal industry has achieved successfully a steady pace of development. According to Shawahid (2015), Malaysia has become a destination for foreign investors to expand its businesses. The positive development has become a platform for SMEs to contribute to the great role in improving the country's economy. Therefore, Small and Medium Enterprises (SMEs) in Malaysia are expected to contribute more than $40 \%$ to the gross domestic product (GDP) of the country by 2020 . Thus, SMEs are urged to get a certified halal certification to seize lucrative opportunities in the global halal sector. To ensure that the process of the whole production is halal, halal SMEs entrepreneurs are suggested to apply the Halal Standards in the sales production process. However, there is still a gap in applying Islamic financial management in the business activities such as financing and investing activities which involve prohibited elements such as usury (riba), uncertainty (gharar) and gambling (maysir).

Malaysia has been established the Halal Standards (HS) set based on good quality value, safe, and trust as a precondition to achieve HS in implementing strategies for the development of the industry. Hence, the authority body is responsible to conduct halal certification and auditing processes is Jabatan Kemajuan Islam Malaysia (JAKIM). The HS is also capable in enhancing good governance in several sectors, business activities, halal supply chain, and halal experts. The terms used in HS are crucial in promoting Malaysia as a global halal hub centre. The development of halal industry can also contribute to good business environment such as a business-friendly ecosystem and network collaboration between related government and private agencies. Therefore, to achieve a holistic view of the HS, there is a need to integrate halal industry with Islamic finance. The HS is highly compliance with Maqasid Syariah to achieve the well-being of the preparation of halal products.

Malaysia has the edge in the development of the Halal industry as it is a modern Islamic country with an open economy and a well developed physical and institutional infrastructure, capable of supporting initiatives and programmes to develop and promote the industry. With this become problems of the study to assess SMEs entrepreneurs sensitivity on Islamic financial management in halal industry activities. The objective of the study is to examine the relationship between knowledge, acceptance and application of Islamic finance in halal operation among SMEs halal entrepreneur in Peninsular of Malaysia. 


\section{SMEs Halal Entrepreneurs}

The definition of SME is mainly based on annual sales turnover and total number of full time occupied by an enterprise (Hashim and Abdullah, 2000; Small and Medium Enterprises Corporation Malaysia [SEMCORP], 2008). According to Hashim, M.K (2000), SME in Malaysia can be categorised into three main sectors which are general business, manufacturing, and agriculture. In Malaysia, according to SMECORP (2008), enterprise that employs 50-150 full-time employees is considered as a medium enterprise, while enterprise that employs 5-50 employees is called small enterprise and less than five employees of employment is considered as a micro enterprise. Mohani Abdul (2008) suggested that incentives should have been formulated to encourage more businesses to go into halal and financial institutions that have targeted SME (SME is a major factor for the growth of the Gross Domestic Product (GDP). In general, SME has established aims to help the government in increasing the income of the state. It also plays an important role in reducing poverty in the society.) in particular to achieve halal certification. Table 1 shows the statistic information on financing sources obtained from the 2011 Economic Census (Profile of Small and Medium Enterprises). In 2010, more than half of the SMEs use their own internal generated funds or funds raised from shareholders to finance their business operations. $21.9 \%$ of SMEs obtained funds through microcredit and from financial institutions such as banks and developed finance corporations. Financial aids obtained from other sources such as grant or fund from government agencies and financial cooperatives were at $28.5 \%$. Based on the size of organisation, the statistic revealed that the fund from financial institutions is the major financing source (51.7\%) for medium-sized SMEs. However, small and micro enterprises rely mainly on internally-generated funds. Only $17.4 \%$ of micro enterprises had secured financing from financial institutions.

The development of halal industry will become more competitive with the involvement of the Islamic finance and banking industry. Although the Islamic finance and banking in Malaysia has been established since 1960s, the system is not yet integrated with halal industry. Today, there are many views from halal experts and political leaders to integrate halal products and Islamic financial system. This information is relevant to be used to show the importance of expanding the halal concept to cover the management for financing aspect. Therefore, the concept of halal products and Islamic financial management should go hand in hand.

There are 56 verses of the Qur'an that mention the word 'Halal' and its root words and 21 verses stress on food consumption. In addition, there are many hadith of the Prophet 
mention about Halal in different contexts and meanings according to the treaties of the Sunnah of the Prophet Muhammad (peace be upon him). There are some indicators that can help to understand the importance of integrating Halal products industry with Islamic banking and finance (Irfan et al., 2016). For instance, a hadith stated by the Prophet (peace be upon him), "those who eat Riba even a dirham, it is as the sin of 33 times of adultery, one that grows out of the meat from illegal sources, then the hell is the key for him" (At-Thabarani, 1983). This hadith shows us that Allah prohibits anyone from committing Riba in total and a very ultimate consequence will occur to those who involve in Riba. Meanwhile, Allah has ordered Muslims to accept Islam as the way of life in total as mentioned in a verse of surah al-Baqarah, "O you who believe, enter into Islam completely (and perfectly..." (Surah Al Baqarah, verse 208). This verse shows us that Allah has brought his order for the people to implement their affairs of life as a holistic system and not separately. Thus, halal concept should also be integrated with the sales operation and also the financing and investing activities through business firms. From the investing activities, halal SME entrepreneur should be aware and occupy knowledges in saving, financing, and investing money based on the Shariah requirement that prohibits interest, gharar, gambling activities, and production of prohibited products. According to Mohd Daud Awang (2017), based on Ibn Khaldun's entrepreneurial economic theory, there are no practices are prohibited by the syarak, particularly in performing muamalat activities.

Daud Vicary Abdullah, the former Chief Executive Officer of the International Centre of Education in Islamic Finance (INCEIF) stated, "to ensure that the whole production process is halal, the source of financing should also be from a halal source, i.e. by using Islamic banking services."

These spirits become a reality through the SMEs halal entrepreneurs in Malaysia via the Eleventh Malaysia Plan, 2016-2020 (11MP). If all of the SMEs halal entrepreneur are required to apply Islamic financial plan in their business activities, this will guarantee a tremendous increase in demand for halal products and halal industry will continue to grow and resembles the holistic view of halal standards in Islam.

\section{Islamic Financial Management}

The dimension of Islamic financial management is grounded based on the demand of Shariah. Islamic financial management is defined as the process of meeting life goals through the management of finances in accordance with the Shariah such as how to increase, create, protect, purify, and distribute wealth based on Shariah guidelines. 
TABLE 1: Sources Of Financing For Sme According To Size Of Enterprise In 2010

\begin{tabular}{l|c|c|c|c|}
\hline Profile Company & \multicolumn{4}{|c|}{ Financial Resources } \\
& $\begin{array}{l}\text { Banking, Microcredit, } \\
\text { And Developed } \\
\text { Finance Institutions }\end{array}$ & $\begin{array}{c}\text { Internally } \\
\text { Generated }\end{array}$ & $\begin{array}{c}\text { Friends And } \\
\text { Family }\end{array}$ & Other Sources \\
\hline Total & 21.9 & 56.1 & 14.3 & 28.5 \\
\hline Micro & 17.4 & 58.1 & 15.0 & 27.5 \\
\hline Small & 33.0 & 49.8 & 12.8 & 31.4 \\
\hline Medium & 51.7 & 47.8 & 8.7 & 32.0 \\
\hline
\end{tabular}

Source: 2011 Economic Census (Profile of Small and Medium Enterprises)

Shariah rules and principles are incorporated into the process of financial management and form the core position in the application of Islamic financial management (Lahsasna, 2010). Hence, Shariah decree has to be observed and adhered throughout the process. Lahsasna (2010) further defined Islamic financial management as a process of determining financial goals, priorities, and resources to be met optimally within the parameters stated by the Shariah. The crux of Islamic financial management is the management itself in pursuit of meeting the individual goals through execution and monitoring of the financial plan. The Islamic teachings always urge Muslims to plan and take necessary actions to ensure they succeed in life. According to al-Maududi, Islam has various ways and rules of business that is compatible with the modern economy which can improve wealth in a fair way.

Thus, the six-step process of financial management seems to be similar in both practices as individuals would set their financial objectives and as well as to strive in achieving those objectives. However, the intention to conduct a financial management based on Shariah and its underlying principles of permissible (halal) transactions distinguishes the implementation measures in both practices. In wealth protection aspect, the Muslims are recommended to apply for a Takaful scheme and to finance halal business operations, while the halal business entrepreneur are recommended to use financing products offered by the Islamic financial institutions or apply a microfinance from an Islamic pawnbroker (Ar-Rahn). Nevertheless, wealth should be kept or invested in products and services provided by Islamic financial institutions.

According to the Islamic teachings, any Muslim who is also a SMEs halal operator is obliged to pay Zakat according to the wealth obtained. Zakat is very important in the economic development process of the Muslim community (ummah). According to Shofian and Amir Husin (2002), the wisdom of zakat or alms can be categorised into two main aspects which are social and economic. From the social view, Zakat can purify the soul of the owner from being arrogant, stingy and individualistic. Nevertheless, the 
concept of Zakat is able to grow and build close relationship within the community and produces individuals who are gracious and generous. Zakat also plays an important role in the community as agents of social security. Economically, the zakat can increase the purchasing power of the society. Zakat is the only form of welfare that is pure that the owner offers sincerely without expecting anything in return other than the consideration of the God Almighty (Shofian and Amir Husin, 2002). This form of sincerity produces healthy activity in the economy as there is no oppression, fraud, usury, and monopoly. In addition, zakat is a mean of social security and it is not meant to gather properties but to redistribute the wealth in immediate assistance to those who are eligible and in need.

Ajzen and Fishbein (1980), Amin et al. (2011), and Jaffar and Musa (2013) suggested that the attitude towards the behaviour refers to the favourable or unfavourable evaluations of the behaviour of an individual and they stated that attitude is positively related with the intention to make use of Islamic personal financings and the attitude is measured using five determinants of attitude which are; awareness and knowledge, religion obligation, cost benefits, business support, and reputation. These attitudes may influence the intention behavioural of entrepreneurs to adopt Islamic methods of finance in business.

\section{Methodology and Data Analysis}

The primary data for this study were obtained from survey questionnaires that were distributed to 200 halal SME entrepreneur in Peninsular Malaysia using random sampling technique. Social Package of Social Science (SPSS) software was used to analyse the relationship between knowledge and acceptance of Islamic finance and application of Islamic financial management among the SMEs halal entrepreneurs.

Reliability means an ability to measure consistency of an instrument. According to McMillan and Schumacher (2006), the reliability level of a certain research tool can be projected by using five methods; namely deciding stability, equivalence, stability and equivalence, internal consistency, and agreement.

Almost all previous researchers tested the reliability of data based on the value coefficient of Cronbach's alpha to valid the data (McMillan and Schumacher, 2006). According to Cates, W.M. (1990), the validation process that the data should achieve is more than $0.85(\alpha>0.85)$. However, this value sometimes is very difficult to obtain for this particular study, therefore, a coefficient with $r$ value more than 0.60 is acceptable (Cates W.M., 1990). On the other hand, coefficient value between 0.6-0.8 can be considered 
as acceptable. Table 2 shown below is the scales used in this study with their reliability analysis.

TABLE 2: Reliability Analysis Of Scales

\begin{tabular}{l|c|c|}
\hline Scale & Number of Item & Cronbach's alpha \\
\hline Knowledge & 35 & 0.68 \\
\hline Acceptance & 31 & 0.90 \\
\hline Application & 22 & 0.83
\end{tabular}

To enable the analysis of parameters that have been carried out, statistical data must be in normal distribution (Bhasah, 2007). In this study, Kolmogorov-Smirnov test and Plot Normal Q-Q were used to determine the normal distribution of data obtained. According to Gravetter and Wallnau (2000) and Bhasah (2007), certain data were considered scatter by normal if its distribution were not significant and the Kolmogorov-Smirnov test showed value that exceeded 0.05 . This study achieved the acceptable value that exceeded 0.05 as the normal distribution as shown in Table 3.

TABLE 3: Test Of Normality

\begin{tabular}{|c|c|c|c|}
\hline \multirow[t]{2}{*}{ Variable } & & $\begin{array}{l}\text { Kolmogorov- } \\
\text { Smirnov }{ }^{a}\end{array}$ & \\
\hline & Statistic & df & Sig. \\
\hline Knowledge & .051 & 200 & $.200^{*}$ \\
\hline Acceptance & .116 & 200 & $.000^{*}$ \\
\hline Application & .062 & 200 & .061 \\
\hline
\end{tabular}

Furthermore, measurement scale intervals from the lowest $(0.00)$ to the highest $(1.00)$ (Majid, 2000) were used in this study. Pearson coefficient was used to seek relationship between two variables. The function of Pearson coefficient measurement is to determine the type and strength of mutual relationship between knowledge, acceptance and application variables. A positive Pearson coefficient value determines direct correlation between two variables studied, while, negative value determines an inverse relationship between the variables (Majid, 2000). The strength of relationship between two variables was determined using Majid (2000) as shown in Table 4.

\section{Discussion}

As we know, the halal industry is a national agenda of Malaysia. The Malaysian government emphasizes on halal industry to boost the economic sector. Therefore, this 
TABLE 4: Strength Of Relationship According To Correlation Value

Correlation Index Value
$0.00-0.20$
$0.21-0.40$
$0.41-0.70$
$0.71-0.90$
$0.91-1.00$

\begin{tabular}{|c|}
\hline Interpretation \\
\hline Very weak \\
\hline Weak \\
\hline Medium \\
\hline Strong \\
Very strong \\
\hline
\end{tabular}

TABLE 5: Correlations Between The Knowledge And Acceptance And Application Of Islamic Financial Management Among Smes Halal Entrepreneur
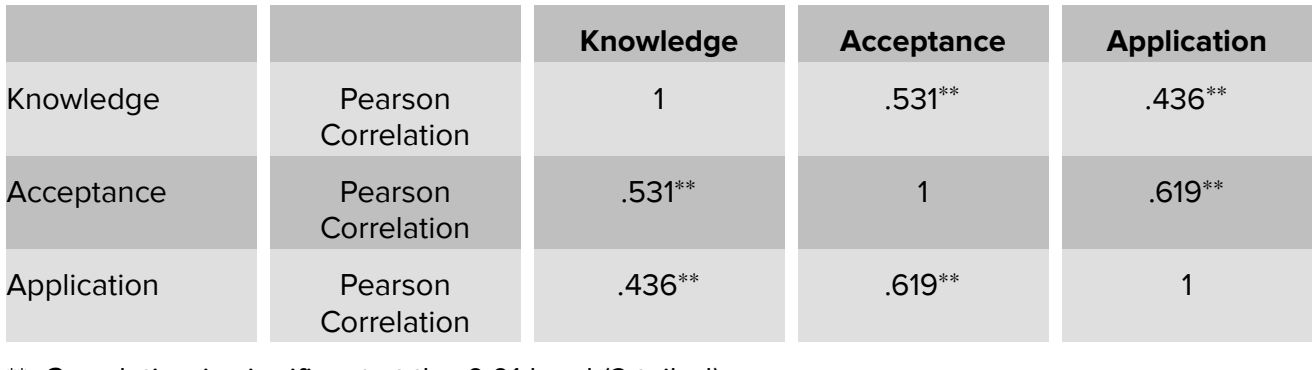

**. Correlation is significant at the 0.01 level (2-tailed)

The Pearson correlation $(r)$ and significant value $(p)$ for this study are shown in Table 5.

study aims to get information in term of acceptance of Islamic financial management in Halal industry. This study focuses on the relationship between knowledge of Islamic finance, acceptance and application of Islamic financial management among SMEs halal entrepreneurs.

This research involves 200 halal entrepreneurs in Peninsular Malaysia using random sampling technique. All data was analysed by using Social Package of Social Science (SPSS). Pearson correlation has been used in determining the strength of relationship between knowledge, acceptance and application variables. There are two hypotheses to be tested in order to discuss on how far the halal entrepreneurs aware the significance of Islamic financial management in their business.

H1: The knowledge of Islamic finance has significant and positive relationship with application of Islamic financial management among SMEs halal entrepreneur.

The statistical findings in table 5 . showed that the proposed hypothesis is supported. The knowledge of Islamic finance showed positive correlation and significantly correlated at medium level with the application of Islamic financial management among halal SMEs entrepreneurs ( $r=0.436, p=.000$ ). The results also manifested positive relationship between the knowledge of Islamic finance and the application of Islamic financial management among halal SMEs entrepreneurs. However, the relationship between these two variables was moderate. 
H2: The acceptance of Islamic finance has significant and positive relationship with application of Islamic financial management among SMEs halal entrepreneurs.

The statistical findings showed that the proposed hypothesis is supported. The acceptance of Islamic finance showed positive correlation and and significantly correlated at medium level with the application of Islamic financial management among SMEs halal entrepreneurs $(r=0.619, p=.000$ ). The results also indicated positive relationship between the acceptances of Islamic finance and the application of Islamic financial management among SMEs halal entrepreneurs.

The objective of the study has been successfully achieved. It has shown that the Islamic financial management is important in halal industry. Therefore, the Islamic finance management should be an important instrument in global halal hub.

\section{Conclusion}

The awareness of Islamic finance among halal entrepreneurs is a positive point to achieve the holistic halal concept. This study has focused on the level of understanding of Islamic finance among SMEs halal entrepreneurs in three terms such as knowledge, acceptance and application in their operation in order to implement the Islamic financial management practices. This leads to the implementation of this study in giving general exposure to SMEs halal entrepreneurs about the importance of the knowledge in halal food production industry. The Malaysian government should give more exposures to SMEs halal entrepreneurs in the form of training or courses about Islamic finance or Islamic financial management because of the integration of the knowledge, acceptance and application of Islamic financial management is strongly and positively correlated the findings of this research. This study also suggests that the Malaysian government should conduct a number of workshop and training to integrate the halal industry with Islamic finance knowledge to enhance the understanding about the holistic view of halal concept among the SMEs entrepreneurs. This study also recommends that the Ministry of Education needs to support the halal development in promoting the knowledge of Islamic finance system with halal products and service industry in education system in Malaysia. The integration of halal industry and Islamic finance is not only could be enhanced the country's economy but it would be enhancing the understanding of the view of Islamic concept of business as well. 


\section{References}

[1] Gay, L. R. \& Airasian P. (2013). Educational Research: Competencies for Analysis and Applications. Upper Saddle River NJ: Pearson Education.

[2] Ajzen, I. and Fishbein, M. (1980). Understanding Attitude and Predicting Social Social Behaviou. NJ: Prentice Hall.

[3] Amin, H., Rahman, A., Sondoh, S.L., and Chooi, A.M. (2011). Determinants of customers' intention to use Islamic Personal Financing. Journal of Is/amic Accounting And Business Research, vol. 2, pp.22-42.

[4] At-Thabarani, M. (1983). Al-Kabir Maktabah Al-Ulumw al-Hikam. Mausoul.

[5] Bhasa, A. (1990). Kaedah analisis data penyelidikan ilmiah. Kuala Lumpur: Utusan Publication.

[6] Cates, W.M. (2007). Panduan Amali Untuk Penyelidikan Pendidikan (Terjemahan). $\mathrm{KL}$ : DBP.

[7] Gay, L.R. (1996). Educational research: Competencies for analysis and application. New Jersey: Prentice Hall.

[8] Gravetter, F. J., and Wallnau, L. B. (2000). Statistics for the Behaviour Sciences (5th ed.). Belmont, CA: Wadsworth.

[9] Hashim, M.K.(2000). A proposed strategic Framework for SMEs success. Malaysian Management Review, vol. 35, issue 2, pp. 32-43.

[10] Hashim, M. K. and Abdullah, M. S. (2000). A Proposed Framework for Redefining SMEs in Malaysia: One Industry, One Definition. Asian Academy of Management Journal, pp. 65-79.

[11] Hilgert, M. A. and Hogarth, J. M. (2003). Household Financial Management: The Connection between Knowledge and Behavior. Federal Reserve bulletin, July issue, pp. 309-322.

[12] Jaffar, M. A. and Musa, R.. (2013). Determinants of Attitude towards Islamic Financing among Halal Certified Micro and SMEs: A Proposed Conceptual Framework. Intenational Journal of Education and Research, vol. 1, issue 8, pp.1-10.

[13] Irfan, I. S., Awang, M. D. and Rahmam, S. A. (2016). The Concept of Halal Economy: An Effort to Integrate the Islamic Banking and Finance in Halal Products Industry in Halal Practices in Economy and Community. Serdang: Penerbit UPM.

[14] Lahsasna, A. (2010). Understanding Shariah Financial Management. Financial 1st Journal, January issue, pp. 40-41.

[15] Awang, M.D., et al. (2014). The Understanding of the Islamic Banking Concept among Muslim Community in Malaysia. Jurnal Muamalat JAKIM, vol. 15. 
[16] McMillan, J. H. and Schumacher, S. (2006). Research in Education. Boston: Pearson Education.

[17] Konting, M. M. (2000). Kaedah Penyelidikan Pendidikan. Kuala Lampur: DBP.

[18] Abdul, M. (2009). H. I. Consumer Decision Making Process in Shopping for Halal Food in Malaysia. China-USA Business Review, vol. 8, issue 9.

[19] Ibrahim, M. Y. (2010). Bimbingan cepat analisis data penyelidikan: Untuk pendidikan dan sains sosial. Bandar IImu: Kuantan.

[20] Ali, N. A. and Mahat, F. (2009). Keupayaan Institusi Pembiayaan Industri Sederhana, Kecil dan Mikro Dalam Melahirkan dan Memperkasakan Usahawan Kecil Yang Berdaya Maju: Ke arah Satu Pendekatan Baru Yang Lebih Berkesan. Kuala Lumpur: Kongres Ekonomi Islam ke 3, Dewan Merdeka PWTC.

[21] Ali, N. A. (2005). Perancangan Kewangan Islam dan konvensional: Analisis Perbandingan dlm. Buku Teori dan Aplikasi Kontemporari Sistem Ekonomi Islam di Malaysia. Kuala Lumpur: Utusan Publication \& Distributors Sdn. Bhd., pp. 17-35.

[22] Norsazali and Awang, M. D. (2017). Ekonomi Keusahawanan Islam Menurut Teori Ibn Khaldun, UMRAN, Volume 3.

[23] Taib, R. A. (2002). Tabung Industri Kecil dan sederhana (IKS): Pelaksanaannya di BIMB. Kuala Lumpur: Kajian ilmiah Akademi Pengajian Islam Universiti Malaya. Reuters.

[24] Shahir, R.M. (2003). Perancangan Kewangan dari Perspektif Syariah. In Massa 383, 2003, pp. 1-7, 23.

[25] Shofian, A. and Husin, A. (2002). M. N. Zakat membangun ummah. Kuala Lumpur: UtusanPublications \& Distributors Sdn. Bhd 